\title{
Wages and innovations in Spanish
}

\section{manufacturing firms}

\author{
ESTER MARTÍNEZ-ROS
}

Universidad Carlos III de Madrid, Department of Business Administration, C/. Madrid, 126, 28903 Getafe, Spain

E-mail: emros@emp.uc3m.es

The question of whether workers take part of the rents when a firm introduces technological changes is studied. Information from a Spanish survey, the Encuesta sobre Estrategias Empresariales covering a period of five years, 1990-1994 is used. Given the data available, panel data techniques are used to control unobserved heterogeneity. A new estimation method proposed by Arellano and Bover (1995) has also been used to improve efficiency results. The results provide confirmation that innovations may be a good approximation to economic rents. In fact, firms which carry out process and product innovations jointly pay larger wages. Moreover, there exists evidence that process innovations and process and product innovations jointly are determined with wages.

\section{INTRODUCTION}

The effect of technological change upon earnings has become an interesting issue to which several microeconometric studies have paid attention lately. ${ }^{1}$ In general, a positive relationship between wages and innovations has been found in the literature because innovation is associated with higher productivity due to greater effort, complementarities with human capital, or upgrading of labour quality. The consideration of these factors leads to the study of the wages and technical activity correlation from a competitive point of view (Dickens and Katz, 1987; Krueger, 1993).

Recently, an alternative view has arisen consisting in that wages are being partly determined by sharing the quasirents. However, the decision about a desirable measure of the source of rents is an important question to take into account. Many economists have pointed out as source of these returns the existence of efficiency wages in the labour market (Krueger and Summers (1988) for the USA, Andrés and García (1991) or Jaumandreu and Martínez-Ros (1995) for Spain). Others emphasize firm's size considerations (Brown and Medoff, 1989). Christofides and Oswald (1992) relate the extra-returns to the per capita profitability and Stewart (1990) to the number of rivals that the firm faces.

Although a large list of variables relating to the source of rents could be stated, another possibility is to consider that rents could be generated by technological innovations (Van Reenen, 1994). The conceptual framework could be established as follows. Innovative returns are the reward for the first commercialization of an invention and lead to a firm prosperity and a large surplus to be divided among employer and workers. If the bargaining between the labour market agents obtain the share in those innovation returns, then it should devote in an increase in the level of pay (Van Reenen, 1993).

The main purpose of this work is to look at the change in the real wage paid by firms when they are engaged in innovation activity and make comparisons with those who do not engage in this activity. The focus is on the idea that technical change can produce some additional profits within the firm. As a result, workers attempt to share these extra-rents by capturing wage increases. Moreover, two alternative measures of rents are employed to carry out this study. The firm specific technical changes are taken distinguishing between process and product innovation. This distinction is important because it corresponds to

\footnotetext{
${ }^{1}$ See, for example, Bound and Johnson (1992) or Bartel and Lichtenberg (1990).
} 
two different outputs of technical change which cause different effects over wages since its determination does not follow the same process (Lunn, 1986).

Individual data for Spanish manufacturing firms during the 1990-1994 period are used. The study is set in a dynamic framework and the nature of the data requires the use of panel data techniques. In this specification least squares estimates may not be consistent because of the potential presence of unobservable effects which are correlated with the lagged real wage. Hence, it is necessary to use alternative methods to overcome this problem. The procedures utilized (Instrumental Variables (IV) or Generalized Method of Moments (GMM)) are based on the ideas of Anderson and Hsiao (AH, hereafter) (1982) or Arellano and Bond (AB) (1991). Alternatively, a new IV method proposed by Arellano and Bover (ABv) (1995) and Blundell and Bond (BB) (1995) is implemented which improves efficiency. The use of this last method is needed by the short time dimension of the data.

The rest of the study contains four sections. In Section II a reference framework is exposed. Section III describes the main features of the data. Section IV presents the econometric treatment of the model and the variables used. Results are presented in Section V. Section VI concludes the paper.

\section{FRAMEWORK}

Technological change is frequently analysed from two opposite points of view. First, the positive one, considers it as a gain in living standards made possible by new technologies. The second point, the negative one, sees the innovation as a threat for some workers who may lose their jobs. The former relies on the idea that innovation rents are the payment for the effort in the introduction of an invention by the firm. Hence, rents could be divided between the employer and the employees. The latter focuses on the effect of innovations on labour demand. In this paper, the approach followed is based on rent sharing explanations. The hypothesis of this theory consists in that efficient companies are more able to share the quasi rents amongst the employees. As a result they enjoy higher wages than those fixed by the labour market and its human capital endowments. At least, three reasons sustain that workers can appropriate a portion of the rents: (i) the long lag of the innovation activity results; (ii) the different horizon of workers' rents with respect the employer and (iii) the hazard elements in the innovative success, which benefit more to workers because they do not suffer the costs of technical activity.

The wage setting follows the insider-outsider approach where incumbent workers are protected by labour turnover costs and by some specific skills which are necessary in the production process (Lindbeck and Snower, 1988, or
Dolado and Bentolila, 1992). Insiders have an interest to maximize rents extracted from the wage bargain with employers. The determination of wages will depend on inside factors (bargaining power and firm's activity) and the alternative income of outside elements. Under such conditions firms may improve its performance by introducing some kind of technological advance in order to increase profits. It leads to incumbent employees to capture some of these extra rents.

In this context, a useful starting point is the standard wage equation (Layard et al., 1991). This framework considers that wage determination comes from a bargaining process between the union and the firm in which wages are explained by the alternative wage workers would face outside the firm $(\omega)$, the bargaining power of the union $(s)$, and other conditions $(X)$.

As explained before, one way to raise economic rents of workers is through the introduction of some technical change by the firm. One could assume that innovations are among the $X$ 's, and they may capture this effect. Hence, it is expected that innovations will have a positive sign because the product quality improvement (either changing the production process and/or creating new products) shifts the labour demand and this leads to higher wages. Since the interest is in verifying the positive impact of innovations on wages, such variable should be isolated from the other conditions. Then the wage determination can be expressed as:

$$
w=w(\omega, s, I, X)
$$

where $I$ is a measure of technological activity.

The positive influence of innovations is justified because a firm which decides to innovate may consider the new technological change as a good instrument to increase its profits. Innovation rents are understood as the reward for the first commercialization of an invention and they take place before technical diffusion does. When a firm adopts a new technology through diffusion it is unlikely to generate substantial rents as it will have to pay a price to purchase the new techniques. The price to pay for innovation may simply be lower research and development spending and one would expect far sighted insiders to reduce their appropriation of the technological fruits of research. The rent-sharing issue focuses on innovation rather than diffusion and positively relates wages with technical change in the empirical work.

\section{DATA DESCRIPTION}

The data base used in this study contains firm level information for the Spanish manufacturing industry from the Encuesta sobre Estrategias Empresariales (ESEE) and covers the period 1990-1994. The ESEE is a survey conducted by the Ministry of Industry and Energy across approxi- 
mately 2000 manufacturing companies. One of the advantages of utilizing this data is the detailed information on innovations and firm's characteristics. The relevant variables for the study are briefly described in the next section.

The survey is a panel with a different number of firms each year but keeping 2188 firms which are followed over time. The sample selection consists of excluding observations with missing values due to problems of data consistency. ${ }^{2}$ We also delete observations for firms which do not report information in any of the three years. Thus, the final sample is a balanced panel with 1306 observations available for each period. This reduced sample is a good representation of the manufacturing industry after comparing the descriptive statistics with those of the complete sample (2188 firms). The observation across this sample leads to classify firms into two wide groups: approximately $65 \%$ are small and medium firms (less than 200 workers) and 35\% are large firms (more than 200 workers). ${ }^{3}$

In general, the Spanish ind ustry was not characterized by much innovative activity but the integration into the European Economic Community (EEC) in 1986, induced firms, in many cases, to change their strategic behaviour. In fact, $45 \%$ of firms in 1992 have introduced some kind of innovation compared with figures of around $15 \%$ in 1986 taken from the Central de Balances survey of the Bank of Spain. ${ }^{4}$ Traditionally, the Spanish industry is mainly composed of small-medium firms with a low percentage of innovation activity but during the 1980s companies have developed some technical change, mainly in process innovation, which might have affected the composition of their labour force as well as their internal capability to face the competitors. It can be argued that entry into the EEC has entailed companies to be more competitive and to try to gain market share both in the internal and foreign markets.

However, a common problem of the technical activity is its measurement. So far, the empirical studies have tried to find good proxies of the source of innovation rents using R\&D expenditure, patents, etc. Sometimes, these measures are not well reported in data sets and may cause misinterpretation of the results (Griliches 1990). In this work, the use of two different measures is proposed: process and product innovations. This provides a new alternative measure compared with other studies, since a more accurate information of technological change is exploited. ${ }^{5}$ One is able to measure the output of innovation activity which generates quite different estimates of the size of spillovers than innovative input do. Moreover, the separation of these technical variables captures the two relevant aspects
Table 1. Pure correlation between wages and innovations

\begin{tabular}{llccc}
\hline & Wages & Product & Process & Both \\
\hline Wages & 1 & & & \\
Product & 0.0062 & 1 & & \\
Process & 0.0880 & -0.1409 & 1 & \\
Both & 0.1662 & -0.1421 & -0.1919 & 1 \\
\hline
\end{tabular}

giving the firm a better advantage: first, if a innovative product occurs, then it affects favourably the firm's market position; second, with the new process, the internal capability of the firm is transformed since it is more efficient and flexible (Geroski et al., 1993).

Both activities are considered outputs of the production process in contrast to the works of Van Reenen (1994) and Geroski et al. (1993) that consider the input of technical change, i.e. R\&D expenditures. The use of an output variable leads one to know what effort has been developed by the firm and how it has been translated in more rents. In addition, the use of different types of innovation adds more and better information than other indicators (patents, for instance) because not all technical change transforms in a patent and because one would not be able to distinguish different behaviours as a result of the introduction of some innovation.

A brief exploration of the data reports that $16 \%$ of firms do both product and process innovation, $9 \%$ innovate only in new products and $16 \%$ only in new processes. However, the behaviour of both types of activity has been different. Product innovation has experienced an increase during the period reaching an $11 \%$ participation in the last year. In contrast, process innovation grew faster up to 1992 and stopped practically increasing in 1994. The indicator that firms engage jointly produce and process innovations provides evidence that this activity increased until 1994. After then, it shows a slightly decline. The explanation of this fact can be that the recession in Spain has had more influence in product than in process innovation. It is what we expect if we think that the process view may be associated with permanent effects on the profitability of the firm while the product view only produces transitory effects.

In order to appraise the link between innovation activity and wages a correlation matrix is presented in Table 1. $A$ priori, process innovation seems to have more influence on wages than the creation of new products. But if both activities are simultaneously done the effect doubles the process

\footnotetext{
${ }^{2}$ Those firms which report zero sales and/or zero employment have been dropped.

${ }^{3}$ For an extensive description of this survey see Segura et al. (1992). A more complete explanation of the data used in this analysis is available from the author on request.

${ }^{4}$ See Labeaga and Martínez-Ros (1994).

${ }^{5}$ Dickens and Katz (1987) and Bartel and Lichtenberg (1990) use industry research and development whereas Nickell et al. (1992) try with Solow residuals.
} 


\begin{tabular}{|c|c|c|c|}
\hline & Innovating only in product & Innovating only in process & Innovating in product and process \\
\hline $\begin{array}{l}\text { Number of Observations } \\
\text { (a) }\end{array}$ & 617 & 1044 & 1059 \\
\hline WAGE & $1.056(0.443)$ & $1.140(0.412)$ & $1.103(0.455)$ \\
\hline SKILLED & $0.035(0.060)$ & $0.033(0.053)$ & $0.046(0.067)$ \\
\hline SEMI-SKILLED & $0.053(0.072)$ & $0.045(0.056)$ & $0.058(0.062)$ \\
\hline UNSKILLED & $0.918(0.101)$ & $0.925(0.082)$ & $0.899(0.099)$ \\
\hline CHEM. AND MET. & $0.263(0.440)$ & $0.316(0.465)$ & $0.272(0.445)$ \\
\hline MECHANICAL & $0.254(0.436)$ & $0.227(0.419)$ & $0.339(0.476)$ \\
\hline FOOD AND DRINK & $0.128(0.334)$ & $0.138(0.345)$ & $0.144(0.352)$ \\
\hline WOODEN & $0.355(0.479)$ & $0.319(0.466)$ & $0.245(0.430)$ \\
\hline \multicolumn{4}{|l|}{ (b) } \\
\hline 1990 & $0.066(0.248)$ & $0.065(0.247)$ & $0.129(0.336)$ \\
\hline 1991 & $0.090(0.287)$ & $0.193(0.395)$ & $0.180(0.384)$ \\
\hline 1992 & $0.106(0.309)$ & $0.183(0.387)$ & $0.168(0.374)$ \\
\hline 1993 & $0.104(0.306)$ & $0.178(0.382)$ & $0.160(0.367)$ \\
\hline 1994 & $0.106(0.308)$ & $0.181(0.385)$ & $0.173(0.378)$ \\
\hline SMALL & $0.096(0.295)$ & $0.135(0.342)$ & $0.099(0.298)$ \\
\hline LARGE & $0.091(0.288)$ & $0.205(0.404)$ & $0.278(0.448)$ \\
\hline CENTRE $^{\mathrm{a}}$ & $0.091(0.288)$ & $0.149(0.356)$ & $0.145(0.352)$ \\
\hline SOUTH & $0.071(0.258)$ & $0.148(0.355)$ & $0.120(0.326)$ \\
\hline NORTH & $0.084(0.278)$ & $0.184(0.388)$ & $0.166(0.372)$ \\
\hline MEDITER & $0.106(0.308)$ & $0.158(0.365)$ & $0.179(0.383)$ \\
\hline
\end{tabular}

Notes: Standard deviations in parentheses.

${ }^{a}$ Regions are aggregated in four categories. Centre: Aragón, C. la Mancha, C. and León and Madrid. South: Andalucía, Extremadura and Canarias. North: Galicia, Asturias, Cantabria, País Vasco, Rioja and Navarra. Mediter: Cataluña, Valencia, Murcia and Baleares.

activity. It could indicate the importance of considering the three technical activities separately.

Tables $2 \mathrm{a}$ and $2 \mathrm{~b}$ summarize the main findings obtained from comparing firms which innovate in a different way. Firms seem to pay their employees better when the innovation process is carried out. It could be feasible to think that the adoption of a new process improves the cost structure and also the efficiency, which confirms the rent-sharing hypothesis. But following this reasoning we expect that process innovating firms would use more skilled workers. The evidence of the sample rejects this because the presence of skilled employees are similar in the two groups of innovating firms. However, when both technical activities are undertaken simultaneously, the share of skilled workers increases significantly. Industry variables show that Leather is the most innovative in product and Chemical and Leather the most innovative in process. The Mechanical sector appears as the most dynamic in the introduction of innovations jointly, the likely reason being that it takes advantage of all the changes produced in computers, vehicles, etc.

Another interesting result of the statistics is the innovation by firm size. We observe that the innovation pattern is similar in both categories of firm who carry out more innovations in process although in different magnitude as expected. Small-medium firms innovate by $14 \%$ in process while large firms do so at $20 \%$. The difference is in the innovations simultaneously, large firms are more prevalent when both activities are done jointly ( $28 \%)$. It confirms the known hypothesis due to Schumpeter that large firms are more capable to appropriate the rents of a technical change.

\section{SPECIFICATION AND ECONOMETRIC TREATMENT}

The theoretical equation implies an empirical specification of the model with the following structural form, which in the case that innovations are exogenous is equivalent to the reduced form:

$$
W_{i t}=\alpha W_{i t-1}+\beta^{\prime} I N O V_{i t}+\gamma^{\prime} S_{i 0}+\delta^{\prime} X_{i t}+\tau_{t}+\varepsilon_{i t}
$$

where $W$ is the wage of firm $i$ in period $t$ (in natural logs), $I N O V$ is a matrix containing innovation variables, $S$ represents the skill composition of the labour force within the firm at the beginning of the period. The $X$ matrix contains other shifters, as an alternative to wages or a measure of firm market position. $\tau$ are time effects considered as additional parameters to be estimated and $\varepsilon_{i t}$ is a random term composed of heterogeneous effects, $\mu_{i}$, and a standard mixed error term, $\nu_{i t}$. Finally, the introduction of lagged wages controls the dynamics in the process of wage determination. An important remark is due here: in this specification the bargaining power is assumed as a parameter which is maximized outside of our study. In Spain, this 
feature is possible since unions do not represent most of the workers but only those who are members; in fact, union members are the insiders who have the bargaining power in the firm, so the pressure of outsiders is not considered.

The dependent variable, $W$, is the firm average wages expressed in logarithms. With respect to the INOV matrix, the possibility to distinguish process from product innovations allows us to determine which kind of activity contributes to obtaining larger quasirents by workers. Therefore, the availability of information about which innovation activity is undertaken by the firm, allows the construction of several alternatives measures. Three variables have been employed: PRODUCT, which takes the value of one when the firm answer affirmatively the question of whether or not it carries out only the development of a new product, and zero otherwise; PROCESS the same as product but only considering the inclusion of a new process, and the same for the variable BOTHINOV when firm engages in both innovations at the same time. With these measures we control for the real innovations since in some cases companies do not report correctly the kind of technical change which are introducing.

In the specification, we also consider variables related to skilled employees as a mechanism to control the labour supply heterogeneity. Thus, we construct three variables measuring the level of qualification defined as the proportion of engineers and degree workers in the firm $(S K I L L E D)$, the proportion of intermediate skilled workers (with a lower degree) (SEMISKILLED) and the proportion of non-degree workers $(N O D E G) .{ }^{6}$ Descriptive statistics of employment reveals a constant structure along the period.

Along with this group we introduce the industry wage as a measure of alternative wage ( $A V G W A G E)$ and a relative measure of size - the market share (SHARE). The macroeconomic shocks are controlled by time dummies (DTt, $t=90, \ldots, 94)$. As an additional control, we have considered the mark-up variable (MARK-UP) as a measure of a firm's profitability. Finally, we have tried to introduce industry dummies to control some external factors which could modify the firm strategy. ${ }^{?}$

An important feature of the panel data is the ability to control unobserved heterogeneous effects (as regards firms in our model). If we consider that $\mu_{i}$ is not observable, the presence of the lagged variable introduces correlation among these effects and the regressors. Hence, OLS or Within Groups (WG) estimates are no longer consistent (Nickell, 1981). In order to take into account the correlation amongst the lagged wage and the effects, there are several possibilities. One is to take first differences in the relevant equation and remove the effects (see $\mathrm{AH}$ or $\mathrm{AB}$ ). The problem is that data are available only for five periods. This transformation and the need to instrument wages in the equation in differences do not recommend the use of this method.

Recently, $\mathrm{ABv}$ and $\mathrm{BB}$ have proposed a new procedure. Under the assumption that the error term in Equation 2 is not serially correlated, the procedure could be instrumented by using the lagged wage growth (a variable which does not contain the effects) in the levels equation. This approach consists of exploiting the initial conditions information for deriving optimal estimators in dynamic panel data models. This is important given the short dimension of the panel because, at the same time, the above problem of correlation is avoided and the efficiency of the estimators is improved (see $\mathrm{ABv}$ ).

On the other hand, if it is considered that technical change is not exogenous because of the possible influence of wages on innovations, then there is a need to instrument them as well. Past innovations could be used for this purpose. This is not unreasonable if it is taken into account that a firm which innovates in the past is more likely to innovate in the future through learning process. Blundell et al. (1995) also confirm the idea of past innovations determining current innovations in the context of a count data model.

\section{MAIN FINDINGS}

In this section some factors are explored that might cause changes on real wages. The first estimation using as instrument $\Delta W_{i t-1}$ revealed the existence of first order serial correlation $\left(m_{1}=10.37\right)$. As it could be induced by misspecification, the first attempt is to include $W_{i t-2}$ in the equation. Although the value of the first order serial correlation test $\left(m_{1}=6.67\right)$ can be reduced the null is rejected as well. Moreover, $W_{i t-2}$ (which is instrumented by $\left.\Delta W_{i t-2}\right)$ is not significant. The presence of autocorrelated errors in the levels equation implies the use of alternative instruments. Following the ABv idea, all models in Table 3 are estimated in levels using the second lag of the wage growth as instrument for wages. This is a valid instrument under the presence of first order serial correlation but in the absence of serial correlation of second order in the residuals $\left(m_{2}=-0.444\right)$.

The availability of specific information about innovations allows one to determine which kind of innovation

\footnotetext{
${ }^{6}$ There is only information of skills variables for 1990 and for 1994 . Under this fact, it is assumed that the employment structure during the first four years do not change. The reference category is NODEG.

${ }^{7}$ There are 18 industry dummies available in the sample, but these have been aggregated into four: Chemicals and metal products; Electrical products, agricultural-industry machinery and motor vehicles; Food, drink and tobacco; and Leather, wooden and paper products. (Chemicals and metals products were chosen as the base industry.)
} 


\begin{tabular}{|c|c|c|c|c|}
\hline & \multirow{2}{*}{$\begin{array}{c}\text { Innovations } \\
\text { Exogenous } \\
\text { (1) }\end{array}$} & \multicolumn{3}{|c|}{$\begin{array}{l}\text { Innovations } \\
\text { Endogenous }\end{array}$} \\
\hline & & (2) & (3) & (4) \\
\hline \multirow[t]{2}{*}{$W A G E_{t-1}$} & 0.597 & 0.598 & 0.598 & 0.571 \\
\hline & 0.223 & 0.222 & 0.212 & 0.208 \\
\hline \multirow[t]{2}{*}{$P R O D U C T$} & 0.026 & 0.027 & 0.025 & 0.029 \\
\hline & 0.017 & 0.039 & 0.020 & 0.021 \\
\hline \multirow[t]{2}{*}{ PROCESS } & 0.054 & 0.061 & 0.027 & 0.029 \\
\hline & 0.024 & 0.054 & 0.042 & 0.040 \\
\hline \multirow[t]{2}{*}{ BOTH } & 0.074 & 0.116 & 0.069 & 0.076 \\
\hline & 0.034 & 0.059 & 0.037 & 0.038 \\
\hline \multirow[t]{2}{*}{ SKILLED } & 1.129 & 1.103 & 0.748 & 0.807 \\
\hline & 0.562 & 0.548 & 0.370 & 0.384 \\
\hline \multirow[t]{2}{*}{ SEMISKILLED } & 0.253 & 0.232 & 0.183 & 0.185 \\
\hline & 0.159 & 0.150 & 0.122 & 0.127 \\
\hline \multirow[t]{2}{*}{$A V G W A G E$} & & & 0.361 & 0.373 \\
\hline & & & 0.155 & 0.151 \\
\hline \multirow[t]{2}{*}{$S H A R E$} & & & 0.017 & 0.018 \\
\hline & & & 0.009 & 0.010 \\
\hline \multirow[t]{2}{*}{$M A R K-U P$} & & & & -0.019 \\
\hline & & & & 0.041 \\
\hline$m_{1}$ & -0.806 & -0.898 & -0.513 & 0.140 \\
\hline Sargan Test (3) ${ }^{c}$ & 3.10 & 2.78 & 2.03 & 1.53 \\
\hline No. observations & 2612 & 2612 & 2612 & 2406 \\
\hline
\end{tabular}

Notes: ${ }^{\text {a }}$ Innovations instrumented by $I_{t-1} \cdot{ }^{\mathrm{b}}$ Columns 3 and 4 only consider process and both innovations as endogenous. ${ }^{c}$ Additional instruments for the Sargan test are lagged innovations. Degrees of freedom in parentheses. All standard errors robust to arbitrary heteroscedasticity. Lagged wage instrumented by $\Delta w_{i t-2}$. All specifications include time and sectoral dummies.

really affects pay. In general, process innovations cause a bigger and more significant effect on wages than product innovation, perhaps because product innovation might not require increased skill whereas process innovation could. The inclusion of a third innovation variable $-B O T H-$ denotes some positive influence. It seems that undertaking both activities simultaneously produce wage increases. One could ask whether product, process or both innovations have different coefficients on wages. After testing it is concluded that the null is rejected in two cases: when one tests that innovation in product is equal to innovation in both activities (at $20 \%$ significance level), and when one tests that innovation in product is equal to innovation in both (at $10 \%$ significance level); in the other case. The null could not be rejected as expected since coefficients of PRODUCT and PROCESS are similar. Finally, the three technical variables are jointly significant as the Wald test (10.15) shows.

Following the idea that the decisions about innovation in the past have influenced the current wage, a set of lagged innovation variables have been included. The introduction of these variables does not change the rest of the coeffi- cients and does not affect the innovation controls either. Moreover, they are not individually and jointly significant (Wald test $=2.15$ ). The reason could be that the technical activity measure in this study is the output of innovation. So, it would not be reasonable to introduce lags of output variables in the determination of an output innovation function since a new process or a new product tomorrow should not affect the current decision about technological innovation.

On one hand, the value of the lagged wage coefficient, which in this context summarizes all past information, remains unchanged. This result, although minor, deserves some attention because it affects the long run effect of all right-hand-side variables. It means that past firm experience significantly affects the current wage determination. The influence is in the same direction and constant along this sample period. On the other hand, labour supply variables such as the worker's qualification has the expected sign. Skilled workers have a more important role in wage decisions than semiskilled workers and both categories have larger effects than non-degree workers. $^{8}$

\footnotetext{
${ }^{8}$ This argument is sustainable in two ways. First, it can be seen in the sample that the employment structure does not change in the period. Second, in three Encuesta de Población Activa is revealed the same employment pattern. Other variables (age, tenure or gender) which could affect the payment are not available. It has been checked, however, that they do not change along the sample period.
} 
Finally, if the evolution of wage is observed a large increase (approximately 26\%) of the wage is found during this period. One observes in the figures of average wages a high growth in $1992(11 \%)$ with an inflexion from there until the end of the time span. Looking at this behaviour it seems necessary to include time variables to control the business cycle.

Up to now, the innovation variables have been restricted to be exogenous in estimating the above specification. From now on this assumption is relaxed and they are included. The main results for the levels equation are summarized in columns 2,3 and 4 of Table 3 . The first column duplicates the earlier analysis taking now all innovations as endogenous while columns 3 and 4 consider product innovation exogenous because the coefficient does not change when moving from (1) to (2). This seems reasonable since product innovation seems to have associated a short time effect in contrast to process innovation which requires a larger term in the production of technical activities. Clearly, the effect of innovations changes when lagged innovations are used as instruments. ${ }^{9}$ It is observed that product innovation continues to be not significant but the coefficient of the process innovation variable (which records those firms which carry out this activity only) has increased although, as expected, the standard error is a bit larger. The $B O T H$ technical activity provides evidence that firms which engage in doing simultaneously both activities are those who really affect workers' pay. Notice that the innovations coefficients in these columns of the table change a lot compared to the first two columns. The likely reason is the endogeneity problem which has been solved after instrumenting. ${ }^{10}$ To test the exogeneity of the three innovation variables we perform variable addition tests. We estimate Probit models separately and include the errors in the specifications. The $t$-ratio is an exogeneity test. Alternatively, we include jointly the errors of all Probits and conduct a $\chi^{2}$ test. As the results between columns 1 and 2 suggest, product innovation is confirmed as an exogenous variable while the test (larger than 2) shows that process and both innovations are endogenous variables. Finally, the Sargan tests confirm the validity of the instruments in each specification. ${ }^{11}$

The results for the rest of the coefficients seem to be robust to the estimation method and remain without variation. Specifically, the lagged wage is highly significant and presents the same magnitude in all specifications. It is also interesting to comment that the inclusion of the alternative wage ${ }^{12}$ and the market share variables have an important role in the determination of pay and show a weak decrease of all coefficients. In fact, the decrease in $P R O C E S S$ and $B O T H$ might indicate that the labour market and firms' strategies discipline the production of some of these innovation activities. Since the interest is in the measure of the wage premium that firms pay to employees when innovation is introduced in the organization, it is obtained that only when firms innovate in process or innovate in both activities simultaneously will employees receive a premium ( $7 \%$ and $20 \%$, respectively). This percentage could motivate workers to make more effort in firms that innovate in process, for instance, because they capture some extra payment. This feed-back effect has been checked and confirmed in Martínez-Ros and Salas (1999).

Moreover, the market share variable is picking up the relative size of the firm, and so it is testing the Brown and Medoff (1989) hypothesis that small companies pay less wages than large ones. These results confirm that the heterogeneity amongst firms also induces a source of interfirm wage differentials. One could consider the possibility of finding these kinds of endogenous variables, however, after instrumenting them we notice that the coefficients of both variables do not change. To be sure that these last variables are not endogenous column 4 has been re-estimated, instrumenting them with their first lags. None of the coefficients have changed in this estimation.

The last column includes a measure of firms' profits as determinant of wages. As this variable was only available for a smaller number of firms, results are reported with a sample of 1203 firms by year. The inclusion of this variable is due to the attempt of measuring which part of the technological rents is appropriated by the entrepreneur. It may be considered to be endogenous since wages and profits could be determined simultaneously. Hence, column 4 provides results instrumenting the mark-up variables with its lags. It is observed that the coefficient is not significant but its introduction in the estimated equation produces changes in the rest of coefficients. Specifically, product innovation improves its significance. It indicates that the product activity has a lighter role in the determination of wages when it is controlled by profitability. There has also been an attempt to disaggregate the mark-up in three intervals (from less to more profitable firms). In this case, the findings allow the inference that the higher the

\footnotetext{
${ }^{9} \mathrm{R} \& \mathrm{D}$ expenditure in 1990 has been used as an additional instrument in this specification. However, these results are not presented because its introduction does not modify the coefficients.

${ }^{10}$ The fact that innovations could be endogeneous is also tested by Van Reenen (1994) without differentiating the kind of technical change. This study has also tried to use the predicted innovations as instruments without significant changes in the results.

${ }_{11}$ All equations include lagged innovations as additional instruments.

${ }^{12}$ Results with regional dummies have been also tried but the main results do not change. Probably, the outside wage is captured by the industry wage and industry dummies as literature related to efficiency wage manifests.
} 
mark-up for the firms, the smaller the rents derived of innovation that accrue to workers.

\section{CONCLUDING REMARKS}

This study has used the ESEE 1990-94 data to examine the effect of innovations on wages. Attention has been focused on alternative explanations of rent-sharing as opposed to the competitive one. Given the available data and having set up the model in a dynamic context, four methods have been used to take into account problems caused by the presence of unobservable effects which are correlated with the lagged wage.

The main findings are summarized as follows. Innovations appear as a source of additional rents for the employees, as expected. It seems that process innovation has a different effect in the determination of the pay than product innovation because of its different determination. In fact, it was observed that when both activities undertaken are dealt with simultaneously, the effect is three times larger than when activities are carried out separately. Employees only capture a wage premium when a firm introduces some new process or new products and new process simultaneously. Furthermore, the data show that product and process innovation are not associated at firm level. Firms that introduce product innovation do not necessarily carry out process innovation (and vice versa).

In econometric terms, the use of the $\mathrm{ABv}$ proposal allows the estimation of a levels equation using instruments in differences which overcomes the problems of correlation among lagged dependent variables and the effects, and improve efficiency over previous methods. A final set of results are presented in which some innovations - process and both - are treated as endogenous. Hence, they confirm the simultaneous determination of both wages and innovations being the innovation activity a good approximation to economic rents.

\section{ACKNOWLEDGEMENTS}

I am extremely grateful to Costas Meghir for his constant advice and encouragement. I also would like to thank Javier Andrés, Jaume García, José M. Labeaga, Pere Ortín, Jumana Saleheen, Ferran Sancho, three anonymous referees, and the review's Editor for many useful comments. Funding from the Spanish Ministry of Education is acknowledged. The usual disclaimer applies.

\section{REFERENCES}

Anderson, T. W. and Hsiao, C. (1982) Formulation and estimation of dynamic models using panel data, Journal of Econometrics, 18, 47-82.
Andrés, J. and García, J. (1991) Una interpretación de las diferencias salariales entre sectores, Investigaciones Económicas, XV(1), 143-47.

Arellano, M. and Bond, S. (1991) Some tests of specification for panel data: Monte Carlo evidence and an application to employment equations, Review of Economic Studies, 58, 277-98.

Arellano, M. and Bover, O. (1995) Another look at the instrumental-variable estimation of error-components models, Journal of Econometrics, 68, 29-51.

Bartel, A. and Lichtenberg, F. (1990) Age of technology and impact on employee wages, Economics of Innovation and New Technology, 1-17.

Blundell, R. W. and Bond, S. (1995) On the use of initial conditions in dynamic panel data models, mimeo.

Blundell, R. W., Griffith, R. and Van Reenen, J. (1995) Dynamic count data models of technological innovation, The Economic Journal, 429, 333-44.

Bound, J. and Johnson, G. (1992) Changes in the structure of wages in the 1980's: an evaluation of alternative explanations, American Economic Review, 82, 371-92.

Brown, C. and Medoff, J. (1989) The employer size-wage effect, Journal of Political Economy, 97, 1027-59.

Christofides, L. N. and Oswald, A. J. (1982) Real wage determination and rent-sharing in collective bargaining agreements, Quarterly Journal of Economics, 3, 985-1002.

Dickens, W. T. and Katz, L. F. (1987) Inter-industry wage differences and industry characteristics in (Eds) $\mathbf{K}$. Lang and J. S. Leonard, Unemployment and the Structure of Labour Markets.

Dolado, J. J. and Bentolila, S. (1992) Who are the insiders? Wage setting in Spanish manufacturing firms, DT 9229, Servicio de Estudios. Banco de España.

Geroski, P., Machin, S. and Van Reenen, J. (1993) The profitability of innovating firms, Rand Journal of Economics, 24, 198-211.

Grilichres, Z. (1990) Patent statistics as economic indicators: a survey, Journal of Economic Literature, XXVIII, 1661-707.

Jaumandreu, J. and Martínez-Ros, E. (1995) Diferencias de coste laboral en la industria: un modelo empírico y su aplicación a las manufacturas españolas in (Eds) J. J. Dolado and J. F. Jimeno, Estudios Sobre el Funcionamiento del Mercado de Trabajo Español.

Krueger, A. B. (1993) How computers have changed the wage structure: evidence from microdata 1984-89, Quarterly Journal of Economics, 108, 33-60.

Krueger, A. B. and Summers, L. H. (1988) Efficiency wages and the inter-industry wage structure, Econometrica, 56, 259-93.

Labeaga, J. M. and Martínez-Ros, E. (1994) Estimación de un modelo de ecuaciones simultáneas con VDL: Una aplicación con datos de la industria Española, Investigaciones Económicas, XVIII(3), 465-89.

Layard, R., Nickell, S. and Jackman, R. (1991) Unemployment Macroeconomic Performance and the Labour Market. Oxford University Press.

Lunn, J. (1986) An empirical analysis of process and product patenting: a simultaneous equation framework, Journal of Industrial Economics, 34, 319-30.

Lindbeck, A. and Snower, D. J. (1988) The InsiderOutsider Theory of Employment and Unemployment. The MIT Press.

Martínez-Ros, E. and Salas, V. (1999) Innovación y salarios en la manufactura Española, Papeles de Economia, 81, 92-103.

Nickell, S. (1981) Biases in dynamic models with fixed effects, Econometrica, 49, 1399-416. 
Nickell, S., Vainiomaki, Y. and Wadhwani, S. (1992) Wages, unions and market structure, Discussion paper no. 77, Center for Economic Performance.

Segura, J. et al. (1992) Un Panorama de la Industria Española. Ministerio de Industria, Comercio y Turismo.

Stewart, M. B. (1990) Union wage differentials, product market influences and the division of rents, The Economic Journal, 100, 1122-37.
Van Reenen, J. (1993) Wages, market structure and innovation: the creation and capture of economic rents, Discussion Paper WP93/2, Institute for Fiscal Studies.

Van Reenen, J. (1994) Getting a fair share of the plunder? Technology, skill and wages in British establishments, Discussion Paper 1881, Centre for Economic Policy Research. 